\title{
CONSUMER VALUE, CONSUMER EXPERIENCE AND CONSUMER SATISFACTION
}

\author{
Lod Sulivyo
}

Sekolah Tinggi Ilmu Ekonomi Ppi, Tangerang, Indonesia sulivyo.lod@stieppi.ac.id

\begin{abstract}
Abstrak
Hubungan antara nilai pelanggan dan kepuasan pelanggan juga terkait dengan nilai pelanggan sebagai persepsi pelanggan tentang konsekuensi yang diinginkan dari penggunaan produk. Semakin tinggi nilai pelanggan, semakin tinggi kepuasan pelanggan. Dengan adanya experiential marketing, pelanggan akan mampu membedakan produk dan jasa yang satu dengan yang lainnya karena pelanggan dapat merasakan dan memperoleh pengalaman secara langsung melalui lima pendekatan (sense, feel, think, act, relate), baik sebelum maupun ketika pelanggan menggunakan sebuah produk atau jasa. Setelah menggunakan produk atau jasa, maka pelanggan akan merasakan adanya kepuasan atau ketidakpuasan sesuai dengan harapan sebelum menggunakan. Semakin tinggi experiential marketing yang dirasakan maka semakin tinggi kepuasan yang dirasakan pelanggan.
\end{abstract}

Keyword: Consumer Value, Consumer Experience, Consumer Satisfaction

\section{PENDAHULUAN}

Tujuan dari suatu bisnis adalah untuk menciptakan para pelanggan yang dapat merasa puas. Terciptanya kepuasan konsumen dapat memberikan manfaat, di antaranya hubungan antara perusahaan dan pelanggan menjadi harmonis, memberikan dasar yang baik bagi pembelian ulang dan terciptanya loyalitas pelanggan, dan membentuk suatu rekomendasi dari mulut ke mulut (word-of-mouth) yang menguntungkan bagi perusahaan (Setiadi, 2003).

Marketing merupakan sesuatu konsep yang difokuskan pada kebutuhan pelanggan sehingga dibutuhkan adanya sesuatu strategi yang terintegrasi dalam rangka menghasilkan keuntungan yang sebanyak-banyaknya melalui kepuasan pelanggan (Gilbert, 2003). Kepuasan dalam hal ini diartikan sebagai suatu respon dan evaluasi konsumen terhadap persepsi antara harapan yang muncul sebelumnya dan apa yang terjadi pada kenyataannya dari produk setelah konsumen melakukan konsumsi (Baran, et al., 2008). Kepuasan merupakan kunci sukses dari strategi marketing yang baik. Kepuasan pelanggan akan meningkatkan loyalitas pelanggan, menurunkan elastisitas harga, membatasi pangsa pasar dari pesaing, menurunkan biaya transaksi, menguragi tingkat kegagalan dari biaya yang dikeluarkan untuk menarik konsumen, serta meningkatkan reputasi perusahaan (Egan, 2008). 
Mencapai tingkat kepuasan pelanggan tertinggi adalah tujuan utama pemasaran. Mempertahankan kepuasan pelanggan dari waktu ke waktu dapat membina hubungan yang baik dengan pelanggan sehingga dapat meningkatkan keuntungan perusahaan dalam jangka panjang. Jika perusahaan hendak memuaskan pelanggan maka pelanggan yang harus diutamakan terlebih dulu adalah pelanggan yang paling potensial dalam hubungan jangka panjang (Tjiptono, 2000). Kepuasan adalah tanggapan pelanggan atas terpenuhinya kebutuhannya. Hal ini berarti penilaian bahwa kinerja suatu barang atau jasa memberikan tingkat kenyamanan yang terkait dengan pemenuhan suatu kebutuhan, termasuk pemenuhan kebutuhan di bawah harapan atau pemenuhan kebutuhan melebihi harapan pelanggan (Kotler, 2008).

Seorang pelanggan yang puas adalah pelanggan yang merasa mendapatkan value dari produsen atau penyedia produk. Value ini bisa berasal dari produk, pelayanan, sistem atau sesuatu yang bersifat emosi. Kalau pelanggan mengatakan bahwa value adalah produk yang berkualitas, maka kepuasan terjadi kalau pelanggan mendapatkan produk yang berkualitas. Kalau value bagi pelanggan adalah kenyamanan maka kepuasan akan datang apabila pelayanan yang diperoleh benar-benar nyaman (Sutisna, 2001). Oleh karena itu customer value mempengaruhi kepuasan pelanggan.

Persepsi yang paling utama bagi pelanggan adalah kepuasan fisik dan mutu. Lebih lanjut dikatakan bahwa kepuasan pelanggan dipengaruhi oleh ciri-ciri produk secara spesifik dan oleh persepsi terhadap kualitas (Mohajerani dan Alireza, 2012). Kepuasan konsumen merupakan penentu yang signifikan dari pengulangan pembelian, informasi dari mulut ke mulut yang positif dan kesetiaan pelanggan. Kepuasan konsumen akan mempengaruhi intensitas perilaku untuk membeli produk dari produsen produk yang sama (Ball dan Machas, 2004). Evaluasi pelanggan terhadap produk berupa evaluasi produk yang diterima apakah sesuai dengan kebutuhan dan harapan pelanggan. Kepuasan adalah Perasaan seseorang mengenai kesenangan atau kecewa dari hasil perbandingan kinerja produk atau layanan yang diterima dengan harapan. Apakah pelanggan puas setelah pembelian tergantung pada kinerja tawaran sehubungan dengan harapan pelanggan. Kepuasan merupakan fungsi dari persepsi atau kesan atas kinerja dan harapan. Harapan dari pelanggan dipengaruhi oleh pengalaman pembelian sebelumnya. Pengalaman (experience) dapat difenisikan sebagai suatu kejadian yang melibatkan seseorang dengan 
ingatannya (Pine dan Gilmore, 1999). Oleh karena itu pengalaman pelanggan (customer experience) mempengaruhi kepuasan pelanggan. Konsep hubungan ini dapat digambarkan sebagai berikut:

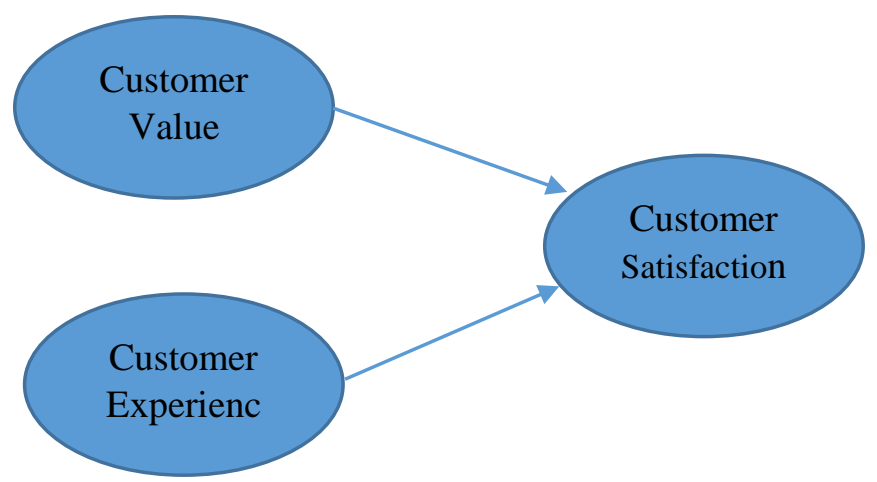

Gambar 1. Kerangka Konseptual

Konsep pemasaran tradisional yang difokuskan pada feature (karakteristik) dan benefit (keuntungan), masih terus dikembangkan oleh kebanyakan praktisi bisnis untuk meraih pangsa pasar yang luas. Strategi pemasaran ini lebih ditekankan pada produk, bukan konsumen, oleh karenanya pemasar menganggap konsumen berfikir melalui suatu proses pengambilan keputusan, yang mana masing-masing karakteristik dari suatu produk, baik barang atau jasa, akan memberikan keuntungan yang jelas, dan karakteristik ini dievaluasi oleh konsumen potensial, baik konsumen yang telah mengenal produk tersebuat maupun yang belum. Oleh karenanya, proses pengambilan keputusan konsumen dilakukan dalam beberapa langkah: mengenali, mencari informasi, mengevaluasi alternatif, melakukan pembelian dan hasil perilaku paska-pembelian (Kotler, 2008). Namun demikian, Schmitt (1999) mengganggap konsep ini sangat membatasi cara pandang pemasar terhadap pengambilan keputusan yang diambil oleh konsumen, yang melibatkan elemen rasionalitas dan logika, serta aspek emosional dan irasional dalam pembelian. Oleh karena itu Schmitt (1999) kemudian mengembangkan suatu konsep baru dalam praktik marketing, yang dikenal dengan "Experiential Marketing", yang lebih berorientasi pada pendekatan psikologis konsumen.

\section{Customer Satisfaction}

Kepuasan merupakan perasaan seseorang yang timbul dari perbandingan kinerja produk yang diterima dengan harapannya. Menurut Kotler (2008) kepuasan 
pelanggan (customer satisfaction) diartikan sebagai fungsi dari seberapa sesuainya harapan pembeli produk dengan kinerja yang dipikirkan pembeli atas produk tersebut Sedangkan menurut Zeithaml, et.al. (2006) kepuasan pelanggan merupakan respon pemenuhan dari konsumen. Hal ini merupakan penilaian mengenai bentuk dari produk dan layanan, atau mengenai produk atau layanan itu sendiri, dalam menyediakan tingkat kepuasan dari konsumsi yang terpenuhi. Jadi untuk memenuhi kepuasan konsumen maka dapat diukur dari sisi kognitif pembeli yang merasa dihargai setara atau tidak setara dengan pengorbanan yang dilakukannya.

Menurut Tjiptono \& Gregorius, (2005) kepuasan dibedakan menjadi tiga tipe dan ketidakpuasan dibedakan menjadi dua tipe:

1. Demanding customer satisfaction, Tipe ini merupakan tipe kepuasan yang aktif. Adanya pengalaman positif dari konsumen, yakni optimisme dan kepercayaan.

2. Stable customer satisfaction, Konsumen dengan tipe ini memiliki tingkat aspirasi pasif dan perilaku yang menuntut. Emosi positifnya terhadap penyedia jasa bercirikan steadiness dan trust dalam relasi yang terbina saat ini. Konsumen menginginkan segala sesuatunya tetap sama.

3. Resigned customer satisfaction, Konsumen dalam tipe ini juga merasa puas. Namun, kepuasannya bukan disebabkan oleh pemenuhan harapan, namun lebih didasarkan pada kesan bahwa tidak realistis untuk berharap lebih.

4. Stable customer dissatisfaction, Konsumen dalam tipe ini tidak puas terhadap kinerjanya, namun pelanggan cenderung tidak melakukan apa-apa.

5. Demanding dissatisfaction, Tipe ini bercirikan tingkat aspirasi aktif dan perilaku menuntut. Pada tingkat emosi, ketidakpuasannya menimbulkan protes dan oposisi

\section{Customer Value}

Zeithaml (1988) mengatakan bahwa customer value adalah evaluasi atas manfaat produk atau layanan yang dirasakan oleh pelanggan dibandingkan dengan apa yang telah dikeluarkan pelanggan untuk mendapatkan produk atau layanan tersebut. Ini menyerupai deskripsi bahwa nilai yang dirasakan pelanggan, yaitu penilaian menyeluruh konsumen terhadap kegunaan produk, berdasarkan persepsi tentang apa yang diterima dan apa yang diberikan. Sementara itu, menurut 
Mashariono dan Oetomo (2006) customer value adalah persepsi pelanggan akan harga, kualitas produk, dan kualitas layanan. Strategi dalam memberikan customer value membutuhkan pengertian yang jelas mengenai value apa yang sesungguhnya diinginkan oleh pelanggan.

Konsep customer value memberikan ide kepada pelanggan tentang perusahaan tersebut, mempertimbangkan apa yang pelanggan inginkan, dan percaya bahwa pelanggan mendapatkan manfaat dari suatu produk. Namun pada akhirnya, pelanggan memaksimalkan value dalam menentukan pilihan akhir pada batasan biaya pencarian serta pengetahuan, mobilitas, dan pendapatan. Pelanggan memperkirakan tawaran mana yang akan menghantarkan value tertinggi dan bertindak atas dasar perkiraan tersebut. Sesuai atau tidaknya suatu penawaran dengan harapan akan mempengaruhi kepuasan pelanggan dan besarnya probabilitas bahwa pelanggan akan menggunakan atau membeli lagi produk tersebut (Kotler, 2008).

Customer value mengacu pada kemampuan perusahaan untuk membuat dan menambahkan nilai pada barang dan jasa, terutama untuk layanan yang ditawarkan kepada pelanggan atau aspek layanan bisnis yang ada (McFarlane, 2013). Kotler (2008) mendefinisikan nilai pelanggan adalah perbandingan pelanggan antara semua keuntungan dan semua biaya yang harus dikeluarkan untuk menerima penawaran yang diberikan. Menurut Kotler (2008), customer value secara umum terdiri dari 4 bagian, yaitu:

1. Product value: nilai produk yang ditawarkan perusahaan kepada konsumen seperti produk-produk yang lengkap dan berkualitas.

2. Service value: nilai yang diberikan perusahaan yang berkaitan dengan pelayanan yang diberikan kepada konsumen, seperti kemudahan dalam hal pembayaran.

3. Personnel value: nilai yang diberikan perusahaan kepada konsumen dengan memiliki personil yang menguasai tugas, ramah, sigap, dan cara berkomunikasi yang baik.

4. Image value: nilai yang diberikan perusahaan kepada konsumen yang berkaitan dengan citra perusahaan tersebut dimata para konsumennya secara khusus dan masyarakat secara umum.

\section{Customer Experience}

Model customer experience adalah suatu model dalam pemasaran yang mengikuti customer equity. Experience adalah peristiwa pribadi yang terjadi 
sebagai jawaban atas beberapa rangsangan. Pengalaman atau experience melibatkan seluruh dalam setiap peristiwa kehidupan. Dengan kata lain, sebagai pemasar harus menata lingkungan yang benar untuk pelanggan dan apa sebenarnya yang diinginkan pelanggan. Melalui pengalaman yang tepat diberikan maka dapat membuat konsumen merasakan sensasi atau hal yang berbeda dalam produk dan jasa.

Customer experience didefinisikan berasal dari satu set interaksi antara pelanggan dan produk, perusahaan, atau bagian dari organisasi, yang menimbulkan reaksi (Tegor \& Husein, 2017). Pengalaman ini benar-benar pribadi dan menyiratkan keterlibatan pelanggan pada tingkat yang berbeda (baik secara rasional, emosional, sensorik, fisik, dan spiritual), customer experience adalah tanggapan pelanggan secara internal dan subjektif sebagai akibat dari interaksi secara langsung maupun tidak langsung dengan perusahaan. Hubungan secara langsung ini biasanya dikarenakan adanya inisiatif dari konsumen. Hal ini biasanya terjadi pada bagian pembelian dan pelayanan. Sedangkan hubungan tidak langsung sering melibatkan perjumpaan yang tidak direncanakan, seperti penampilan produk dan merek, iklan, dan event promosi lainnya.

Menurut Chen \& Lin (2014) customer experience didefinisikan sebagai pengakuan kognitif atau persepsi menstimulasi motivasi pelanggan. Pengakuan atau persepsi tersebut dapat meningkatkan nilai produk dan jasa. Customer experience merupakan hasil interaksi konsumen dengan perusahaan secara fisik dan emosional. Hasil interaksi ini dapat membekas di benak konsumen dan mempengaruhi penilaian konsumen terhadap perusahaan. Schmitt (1999) menyarankan ada lima tipe customer experience sebagai dasar untuk analisis pemasaran pengalaman keseluruhan, yakni: sense, feel, think, act, dan relate.

\section{Experiential Marketing}

Menurut Pine dan Gilmore (1996) pengalaman merupakan suatu peristiwa yang terjadi dan dirasakan oleh masing-masing individu secara personal yang dapat memberikan kesan tersendiri bagi individu yang merasakannya. Dengan kata lain, pengalaman juga merupakan hasil dari pengamatan atau partisipasi individu pada suatu peristiwa, dimana peristiwa itu adalah nyata dan apa yang sebenarnya terjadi. 
Oleh karenanya, pengalaman akan melibatkan kedua sisi kehidupan manusia, yaitu sisi rasional dan emosional. Sedangkan pemasaran menurut Kotler (2008), adalah suatu proses sosial yang didalamnya individu dan kelompok mendapatkan apa yang diperlukan dan inginkan dalam menciptakan, menawarkan, saling bertukar produk dan jasa yang bernilai secara bebas dengan pihak lain. Adapun beberapa pengertian Experiential Marketing menurut para ahli adalah sebagai berikut:

1. Experiential marketing adalah suatu konsep pemasaran yang bertujuan untuk membentuk pelanggan-pelanggan yang loyal dengan menyentuh emosi pelanggan dan memberikan suatu feeling yang positif terhadap produk dan service (Kartajaya, 2004).

2. Expeririential Marketing dapat diartikan sebagai sebuah perpaduan antara praktis pemasaran non-tradisional dan modern yang diintegrasikan dalam rangka meningkatkan pengalaman personal dan emosioanal terhadap merek (Andreani, 2007).

3. Expeririential Marketing merupakan suatu pendekatan yang dilakukan untuk memberikan informasi sebanyak-banyaknya mengenai suatu produk atau jasa kepada konsumen (Pine dan Gilmore, 1996).

4. Experiential Marketing adalah proses mengidentifikasi dan memuaskan kebutuhan dan keinginan yang menguntungkan konsumen, dengan melibatkan pelanggan melalui komunikasi dua arah yang membawa kepribadian merek pada kehidupan kosnumen yang menjadi target, untuk dapat berkembang dan menambah nilai produk pada sasaran yang menjadi target (Smilansky, 2009).

Schmitt dan Rogers (2008) menerangkan kerangka analisis Experiential Marketing melalui dua aspek yang menjadi pilar pendekatan experiential marketing yang menurut sudut pandang praktisi dan profesional akan sangat membantu memahami bagaimana seharusnya menciptakan kampanye pemasaran yang dapat menyentuh berbagai pengalaman yang spesifik dengan konsumen, yaitu Strategic Experiential Moduls (SEMs) dan Experiential Provider(ExPros). Namun pada penelitian ini, peneliti hanya menggunakan kerangka Strategic Experiential Moduls (SEMs).

Menurut Schmitt dan Rogers (2008), Strategic Experiential Moduls (SEMs) merupakan kerangka Experiential Marketing yang terdiri dari pengalaman melalui indera (sense), pengalaman afektif (feel), pengalaman kognitif kreatif (think), pengalaman fisik dan keseluruhan gaya hidup (act), serta pengalaman yang menimbulkan hubungan dengan kelompok referensi atau kultur tertentu (relate). Adapun 5 indikator pengalaman yang dimaksud dapat dijelaskan sebagai berikut: 
1. Sense

Sense (pengalaman indera) adalah usaha untuk menciptakan pengalaman yang berkaitan dengan panca indra melalui penglihatan, suara, sentuhan, rasa dan bau. Tujuan utama membentuk pengalaman indera adalah sebagai:

a. Differentiator (pembeda)

Sebagai pembeda, pengalaman indera berujuan untuk menampilkan identitas atau ciri khas tertentu yang tampak melalui stimulus, yakni dengan memberikan perhatian dan menjadikan informasi agar lebih menarik dari biasanya bisa melalui musik, warna atau tampilan agar tetap up to date.

b. Motivator (pemberi motivasi)

Sebagai motivator, pengalaman indera bertujuan untuk memberi motivasi kepada konsumen untuk mencoba produk dan membelinya. Dalam hal ini, pengalaman indera dapat diterapkan melalui tiga cara, yaitu:

1) Across modalities, dimana pengalaman indera disajikan dengan menggunakan multi media, dengan mengkombinasikan penampilan, pendengaran, penciuman dalam menyampaikan informasi;

2) Across expres, dimana pengalaman indera disajikan menerapkan image (kesan tertentu) pada proroduk atau jasa. Hal ini berhubungan dengan tingkat konsistensi elemen yang berkaitan panca indra;

3) Across space and time, dimana pengalaman indera disajikan melalui gaya, tema, slogan, warna, orang yang digunakan dalam iklan, pencahayaan dan struktur organisasi.

c. Add Value (memberi nilai)

Dalam hal ini, pengalaman indera bertujuan untuk menggabungkan seluruh komponen yang berkaitan dengan panca indra (atribut, gaya dan tema) sebagai bagian dari sense strategies (cognitive consistency/sensory variety).

2. Feel

Feel (pengalaman afektif) merupakan strategi dan implementasi untuk memberikan pengaruh merek kepada konsumen melalui komunikasi (iklan), produk (kemasan dan isinya), identitas produk (co-branding), lingkungan, websites, orang yang menawarkan produk. Setiap perusahaan harus memiliki pemahaman yang 
jelas mengenai cara penciptaan perasaan melalui pengalaman konsumsi yang dapat menggerakkan imajinasi konsumen yang diharapkan konsumen dapat membuat keputusan untuk membeli. Pengalaman afektif adalah hasil kontak dan interaksi yang berkembang sepanjang waktu, di mana dapat dilakukan melalui perasaan dan emosi yang ditimbulkan. Selain itu juga dapat ditampilkan melalui ide dan kesenangan serta reputasi akan pelayanan konsumen. Tujuan utama membentuk pengalaman afektif adalah untuk menggerakkan stimulus emosional (events, agents and objects) sebagai bagian dari feel strategies sehingga dapat mempengaruhi emosi dan suasana hati konsumen.

Pengalaman afektif merupakan pengalaman yang tercipta sedikit demi sedikit, yaitu perasaan yang berubah-ubah, jarak antara mood yang positif atau negatif kepada emosi yang kuat. Adapun hal-hal yang perlu diperhatikan berkaitan dengan pengalaman afektif adalah:

a. Suasana hati (moods)

Moods merupakan pernyataan affective yang tidak spesifik. Suasana hati dapat dibangkitkan dengan cara memberi stimuli yang spesifik. Suasana hati seringkali mempunyai dampak yang kuat terhadap apa yang diingat konsumen dan merek apa yang akan konsumen pilih.

b. Emosi (emotion)

Emosi lebih kuat dibandingkan dengan suasana hati dan merupakan pernyataan affective dari stimulus yang spesifik. Misalnya marah, iri hati dan cinta. Emosi-emosi tersebut disebabkan oleh sesuatu/ seseorang (orang, peristiwa, perusahaan, produk atau komunikasi).

\section{Think}

Think (pengalaman kognitif kreatif) dilakukan untuk mendorong konsumen sehingga tertarik dan berpikir secara kreatif sehingga mungkin dapat menghasilkan evaluasi kembali mengenai perusahaan dan merek tersebut. Pengalaman ini lebih mengacu pada masa depan, fokus, nilai, kualitas dan perkembangan, serta dapat ditampilkan melalui hal-hal yang memberi inspirasi, teknologi dan kejutan.

4. Act

Act (pengalaman fisik dan gaya hidup) merupakan upaya untuk menciptakan pengalaman konsumen yang berhubungan dengan tubuh secara fisik, pola perilaku, dan gaya hidup dalam jangka panjang, berdasarkan pengalaman yang terjadi dari 
interaksi dengan orang lain. Di mana gaya hidup sendiri merupakan pola perilaku individu dalam hidup yang direfleksikan dalam tindakan, minat dan pendapat. Penciptaan pengalaman fisik dan keseluruhan gaya hidup dapat diterapkan dengan menggunakan trend yang sedang berlangsung, atau dengan mendorong terciptanya trend budaya baru. Tujuan penciptaan pengalaman fisik dan gaya hidup adalah untuk memberikan kesan terhadap pola perilaku dan gaya hidup, serta memperkaya pola interaksi sosial melalui strategi yang dilakukan.

5. Relate

Relate (pengalaman identitas sosial) merupakan gabungan dari keempat aspek Experiential Marketing, yaitu: sense, feel, think dan act. Pengalaman identitas sosial ditunjukkan melalui hubungan dengan orang lain, kelompok lain (misalnya pekerjaan, gaya hidup) atau komunitas sosial yang lebih luas dan abstrak (misalnya negara, masyarakat, budaya). Dalam hal ini, tujuan dari penciptaan pengalaman identitas sosial adalah untuk menghubungkan konsumen dengan budaya dan lingkungan sosial yang dicerminkan oleh produk atau jasa.

\section{KESIMPULAN}

\section{Pengaruh Customer value terhadap Customer Satisfaction}

Nilai pelanggan adalah pilihan yang dirasakan pelanggan dan evaluasi terhadap atribut produk, kinerja atribut dan konsekuensi yang timbul dari penggunaan produk untuk mencapai tujuan dan maksud konsumen ketika menggunakan produk. Adapun kaitan nilai pelanggan terhadap kepuasan pelanggan juga dikaitkan dengan nilai pelanggan sebagai persepsi pelanggan terhadap konsekuensi yang diinginkan dari penggunaan produk tersebut.

Semakin tinggi nilai pelanggan maka semakin tinggi kepuasan pelanggan. Selanjutnya dapat juga didefinisikan nilai pelanggan sebagai persepsi pelanggan terhadap konsekuensi yang diinginkan dari penggunaan sebuah produk. Arti penting dari nilai pelanggan adalah sebuah konsep yang paling banyak digunakan oleh pelaku bisnis. Ini adalah sebuah konsep sederhana dan dapat digunakan sebagai langkah awal perumusan strategi selanjutnya (Mohajareni dan Alireza, 2012). Banyak keputusan strategis perusahaan menggunakan konsep ini sebagai landasan utamanya, walaupun seringkali tidak terformulasikan dengan baik. 
Perusahaan tidak menggunakan hitungan-hitungan sistematis dengan analisa data yang canggih tetapi melalui judgment. Secara sederhana, nilai pelanggan didefinisikan sebagai semua manfaat atau kualitas yang diperoleh oleh konsumen relatif terhadap pengorbanannya. Nilai pelanggan adalah total manfaat atau kualitas dibagi dengan harga. Selanjutnya, rumus ini bisa berkembang karena adanya dua aspek. Aspek tersebut adalah harga dan kualitas. Kedua aspek tersebut merupakan multidimensi (Heinonen, 2004).

\section{Pengaruh Customer Experience terhadap Customer Satisfaction}

Experiential Marketing adalah suatu usaha yang digunakan oleh perusahaan atau pemasar untuk mengemas produk sehingga mampu menawarkan pengalaman emosi hingga menyeluruh hati dan perasaan konsumen (Andreani,s2007). Pengalaman konsumen dalam mengkonsumsi barang dan jasa erat kaitannya dengan konsep experiential marketing. Experiential marketing dapat sangat berguna untuk sebuah perusahaan yang ingin meningkatkan merek yang sangat berguna untuk sebuah perusahaan yang ingin meningkatkan merek yang berada pada tahap penurunan, membedakan produk perusahaan dari produk pesaing, menciptakan sebuah citra dan identitas untuk sebuah perusahaan, meningkatkan inovasi dan membujuk pelanggan untuk mencoba dan membeli produk (Maghnati et al., 2012).

Dalam kondisi sekarang, experiential marketing perusahaan tidak hanya berorientasi pada fitur dan benefit tetapi juga mengutamakan emosi pelanggan dengan memberikan fasilitas-fasilitas yang bisa memberikan kepuasan bagi pelanggan (Schmit, 1999). Dengan adanya experiential marketing, pelanggan akan mampu membedakan produk dan jasa yang satu dengan yang lainnya karena pelanggan dapat merasakan dan memperoleh pengalaman secara langsung melalui lima pendekatan (sense, feel, think, act, relate), baik sebelum maupun ketika pelanggan menggunakan sebuah produk atau jasa. Setelah menggunakan produk atau jasa, maka pelanggan akan merasakan adanya kepuasan atau ketidakpuasan sesuai dengan harapan sebelum menggunakan. Semakin tinggi experiential marketing yang dirasakan maka semakin tinggi kepuasan yang dirasakan pelanggan. 


\section{DAFTAR PUSTAKA}

Andreani, Fransisca. (2007). Experiential Marketing (Sebuah Pendekatan Pemasaran). Jurnal Manajemen Pemasaran, Vol.2, No.1.

Ball, D dan Machas, A. (2004). The role of communication and trust in explaining customer loyalty an extension to the European Customer Satisfaction. Journal of Marketing, Vol. 38, No. 9.

Baran, R. et al. (2008). Principle of Customer Relationship Management. Ohio: Thomson South-Western.

Chen, S. C and Lin, C. P. (2014). The impact of customer experience and perceived value on sustainable social relationship in blogs: An empirical study.Technological Forecasting \& Social Change, Vol. 96.

Egan, J. (2008). Relational Marketing: Exploring Relational Strategies in Marketing, (4th edition). New Jersey: Prentice Hall.

Gilbert, David. (2003). Retail marketing management (2nd ed.). England: Prentice Hall.

Heinonen, K. (2004). Reconceptualizing customer perceived Value: the value of time and place. Managing Service Quality, Vol. 14, No. 2.

Kartajaya, Hermawan. (2004). Marketing In Venus. Jakarta: Gramedia.

Kotler, Philip. (2008). Principles of Marketing. New Jersey: Prentice Hall.

Maghnati, Fashad. et al. (2012). Exploring the Relationship between Experiential Marketing and Experiential Value in The Smartphone Industry. International Business Research Vol. 5, No. 11.

Mashariono \& Oetomo, H. W. (2003). Analisis Nilai Pelanggan yang Mempengaruhi Loyalitas (Studi Kasus Pada Bank KBPR Jetis Ponorogo. Ekuitas, Vol. 10, No. 2.

McFarlane, D. A. (2013). The Strategic Importance of Customer Value. Atlantic Marketing Journal, Vol. 2, No. 1.

Mohajerani, P. \& Alireza, M. (2012). Customer Satisfaction Modeling in Hotel Industry: A Case Study of Kish Island in Iran. International Journal of Marketing Studies, Vol. 4, No. 3.

Pine, B. J. \& Gilmore H. J. (1999). The Experience Economy: Work is Theatre and Every Business a Stage. Boston: Harvard Business School Press.

Prahalad, C. K. \& Ramaswamy, V. (2000). Co-opting Customer Competence. Harvard Business Review, Vol. 78, No. 1.

Schmitt, H. B. (1999). Experiential Marketing: How to Get Your Customer to Sense, Feel, Think, Act and Relate to Your Company and Brands. New York: The FreePress.

Schmitt, H. Bernd, dan David L. Rogers. (2008). Handbook on Brand and Experience Management. UK: Edward Elgar Publishing.

Setiadi, N. (2003). Perilaku Konsumen. Jakarta: Kencana Prenada Media.

Smilansky, S. (2009). Experiential Marketing: A Practical Guide to Interactive Brand Experiences. London and Philadelphia: Kogan Page.

Sutisna. (2001). Perilaku Konsumen dan Komunikasi Pemasaran. Bandung: Remaja Rosdakarya.

Tegor, \& Husein, U. (2017). Compensation analysis in relationship moderation between transformational leadership style and work environment on the employee performance. Russian Journal of Agricultural and Socio-Economic Sciences, 71(11), 312-323. doi:10.18551/rjoas.2017-11.40

Tjiptono, F. (2000). Manajemen Jasa. Yogyakarta: Penerbit Andi.

Tjiptono, F. \& Gregorius C. (2005). Service, Quality, and Satisfaction. Yogyakarta: Penerbit Andi.

Zeithaml, V. A. (1988). Consumer Perception of Price, Quality and Value: A MeansEnd Model and Synthesis of Evidence. Journal of Marketing, Vol. 52, No. 3.

Zeithaml, V. A. \& Bitner, M. J. (2006). Marketing. New York: Mc. Graw Hill. 